\title{
"The effects of the International Financial Reporting Standards (IFRS) adoption on earnings quality: evidence from Korea"
}

\begin{tabular}{|c|c|}
\hline AUTHORS & $\begin{array}{l}\text { Jee Hoon Yuk } \\
\text { Wook Bin Leem }\end{array}$ \\
\hline ARTICLE INFO & $\begin{array}{l}\text { Jee Hoon Yuk and Wook Bin Leem (2017). The effects of the International } \\
\text { Financial Reporting Standards (IFRS) adoption on earnings quality: evidence } \\
\text { from Korea. Investment Management and Financial Innovations, 14(3), 243-250. } \\
\text { doi:10.21511/imfi.14(3-1).2017.08 }\end{array}$ \\
\hline DOI & http://dx.doi.org/10.21511/imfi.14(3-1).2017.08 \\
\hline RELEASED ON & Monday, 13 November 2017 \\
\hline RECEIVED ON & Friday, 28 July 2017 \\
\hline ACCEPTED ON & Thursday, 14 September 2017 \\
\hline LICENSE & $\begin{array}{l}(c) \text { EY-NC } \\
\text { This work is licensed under a Creative Commons Attribution-NonCommercial } 4.0 \\
\text { International License }\end{array}$ \\
\hline JOURNAL & "Investment Management and Financial Innovations" \\
\hline ISSN PRINT & $1810-4967$ \\
\hline ISSN ONLINE & $1812-9358$ \\
\hline PUBLISHER & LLC "Consulting Publishing Company "Business Perspectives" \\
\hline FOUNDER & LLC "Consulting Publishing Company "Business Perspectives" \\
\hline
\end{tabular}

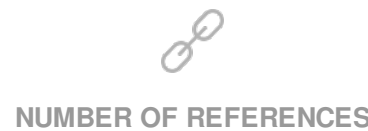

11
NUMBER OF FIGURES

0
NUMBER OF TABLES

4

(c) The author(s) 2023. This publication is an open access article. 


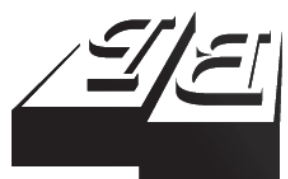

BUSINESS PERSPECTIVES

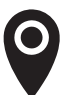

LLC "CPC "Business Perspectives" Hryhorii Skovoroda lane, 10, Sumy, 40022, Ukraine

www.businessperspectives.org

Received on: $28^{\text {th }}$ of July, 2017 Accepted on: $14^{\text {th }}$ of September, 2017

(c) Jee Hoon Yuk, Wook Bin Leem, 2017

Jee Hoon Yuk, Ph.D., Assistant Professor, Da Vinci College of General Education, Chung-Ang University, Republic of Korea.

Wook Bin Leem, Ph.D., Assistant Professor, Department of Business Administration, ShinGyeong University, Republic of Korea.

\section{(ㄷ)(1) $(8)$}

This is an Open Access article, distributed under the terms of the Creative Commons Attribution-NonCommercial 4.0 International license, which permits re-use, distribution, and reproduction, provided the materials aren't used for commercial purposes and the original work is properly cited.
THE EFFECTS OF THE INTERNATIONAL FINANCIAL REPORTING STANDARDS (IFRS) ADOPTION ON EARNINGS QUALITY: EVIDENCE FROM KOREA

\begin{abstract}
This study investigates whether earnings quality of Korean listed firms was substantially improved after the IFRS adoption in long-term aspect and which firms listed in KOSPI or KOSDAQ market had been more enjoyed the benefit. Prior studies related to this subject don't provide consistent results and have a limitation of insufficiency of research periods. Therefore, this study analyzes the positive effect of the IFRS adoption in Korea using long-term based approach and comparative analysis on each Korean stock market. Furthermore, this study considered Korean specific institutional environment in which main financial statements prepared and disclosed by listed firms were changed from individual financial statements to consolidated financial statements after the IFRS adoption. Results of the study found that earnings quality of Korean listed firms had been significantly improved during 5 years after the IFRS adoption. In addition, earnings quality on consolidated financial statements of KOSDAQ listed firms has improved more than that of KOSPI listed firms. The results provide meaningful implications to evaluate the effects of IFRS adoption on earnings quality and to assess accomplishment of fundamental purpose of the IFRS adoption in Korea.
\end{abstract}

Keywords

IFRS, earnings quality, modified Jones model, performance-matched discretionary accruals model, KOSPI, KOSDAQ

JEL Classification $\quad$ M41

\section{INTRODUCTION}

Korea adopted International Financial Reporting Standards (IFRS) in 2011 to improve international consistency of financial accounting standards and to enhance both accounting transparency and usefulness of accounting information. Especially, the main objective of the IFRS adoption in Korea was to provide accounting information users with more useful information and to eliminate Korea discount by improving accounting transparency.

One of the positive effects of the IFRS adoption is that earnings quality can be improved in comparison with pre-IFRS adoption period. Barth et al. (2008) and Chen et al. (2010) report that earnings quality has improved, as earnings management was reduced after the adoption of IFRS.

However, unlike previous financial accounting standards in Korea (referred as 'K-GAAP') which applied rule-based approach, the IFRS applies principle-based approach. Thus, the adoption of IFRS may be a factor to degenerate earnings quality, because discretion of manager on accounting choice increases after the IFRS adoption. Callao and 
Jarne (2010), as well as Li and Park (2012), suggest that earnings management measured by discretionary accruals increased after the IFRS adoption. Additionally, Bae and Choi (2013) and Jeong (2013) which analyzed Korean firms report that earnings management increased after the IFRS adoption. Tendeloo and Vanstraelen (2005) also report that there was no difference in earnings management between the IFRS-adapted firms and local GAAP-adapted firms.

Meanwhile, Korean stock markets consist of KOSPI market and KOSDAQ market. Since KOSDAQ market has simple listing requirement and is mainly comprised of venture businesses which are small, risky, but with high growth potentiality, KOSDAQ listed firms may have higher incentive of earnings management than KOSPI listed firms. Thus, if earnings quality is improved as earnings management decreases after adoption of the IFRS, such improvement may be more striking at KOSDAQ listed firms than KOSPI listed firms.

Hence, this study investigates whether earnings quality of Korean listed firms was substantially improved after the IFRS adoption ${ }^{1}$. Specifically, unlike prior studies of Korea which analyzed the effect of IFRS adoption on the earnings quality in short-term aspect, this study analyzes the effect in long-term aspect by comparing 5 years before IFRS adoption with 5 years after IFRS adoption. In addition, this study divides sample firms into 2 groups (KOSPI listed firms and KOSDAQ listed firms) and analyzes the effect of IFRS adoption on the earnings quality respectively. Moreover, this study considered Korean specific institutional environment in which main financial statements prepared and disclosed by listed firms were changed from individual financial statements to consolidated financial statements after the IFRS adoption.

The results of this study show that earnings quality of Korean firms has significantly improved during 5 years after the IFRS adoption compared with 5 years before IFRS adoption. Moreover, earnings quality on consolidated financial statements of KOSDAQ listed firms has improved more than that of KOSPI listed firms. This study is distinct from prior studies in that it analyzed the effect of the IFRS adoption on earnings quality using long-term approach and analyzed comparative effect for each stock market. This study provides accounting information users and regulatory authorities with meaningful implications in that it confirms that the fundamental objective of the IFRS adoption in Korea is continuously attained.

\section{LITERATURE REVIEW AND HYPOTHESES}

Prior studies which analyzed effect of the IFRS adoption on earnings quality provide inconsistent results. Some studies report that earnings quality has improved after the IFRS adoption (Barth et al., 2008; Chen et al., 2010) while other studies suggest earnings quality was deteriorated after the IFRS adoption (Callao \& Jarne, 2010; Li \& Park, 2012; Bae \& Choi, 2013; Jeong, 2013). Moreover, Tendeloo and Vanstraelen (2005) report no substantial difference in earnings quality before and after IFRS adoption.

Specifically, Barth et al. (2008) analyzed the effect of IFRS adoption on earnings quality for firms in 21 countries which adopted the IFRS. The re- sult showed that earnings quality has improved, as earnings management and income smoothing have decreased after IFRS adoption. Chen et al. (2010) which analyzed 15 member countries of EU also reported similar results.

On the contrary, Callao and Jarne (2010) who studied on non-financial firms in 11 member countries of EU reported that earnings management measured by discretionary accruals increased after the IFRS adoption. Li and Park (2012) which studied on Chinese firms also reported that earnings quality reduced as discretionary accruals increased after the IFRS adoption. Especially, Bae and Choi (2013) which analyzed Korean firms showed that earnings management increased through abnormal operating activity and abnormal manufacturing cost after the IFRS adoption. Jeong (2013) also argued

$1 \quad$ All listed firms in Korea have mandatorily applied the IFRS as their accounting standard since 2011, whereas unlisted firms have applied Korean GAAP which has been established and revised by the Korean Accounting Standards Board (KASB). It is permitted for unlisted firms to apply the IFRS voluntarily, however, any listed firms are not allowed to apply the Korean GAAP. 
that while earnings quality measured by discretionary accruals has improved on individual financial statement after the IFRS adoption, earnings quality on consolidated financial statement has reduced.

Further, Tendeloo and Vanstraelen (2005) analyzed whether there was significant difference of earnings management between German firms which early adopted the IFRS and those which applied German GAAP. The result found there was no significant difference of earnings management between two groups. In short, prior studies didn't provide consistent conclusions on effect of the IFRS adoption on earnings quality. Therefore, we establish the first hypothesis as follows ${ }^{2}$.

H1: Earnings quality of Korean listed firms would not be different after the IFRS adoption in comparison with the earnings quality before the IFRS adoption.

The listing requirements of KOSPI and KOSDAQ market in Korea are different, as well as characteristics of firms listed in each stock market. While KOSPI market is composed of relatively large firms, KOSDAQ market is composed of small and medium venture businesses with high growth potentiality. Thus, such difference of each stock market may affect on earnings management of listed firms. For instance, Yoon and Kim (2007) reported that KOSDAQ listed firms tended to manage their earnings more upward before initial public offering (IPO) than KOSPI listed firms. Furthermore, Moon (2017) suggested earnings quality of KOSPI listed firms was much better than KOSDAQ listed firms.

Inferring from those prior studies, if earnings quality of Korean listed firms is improved after the IFRS adoption, such positive effect may exist distinctively depending on stock market. Specifically, the effect of improving earnings quality after the IFRS adoption is likely to be greater for KOSDAQ listed firms than KOSPI listed firms. It is because earnings management is performed more strikingly at KOSDAQ listed firms following prior studies and such earnings management can be restrained by the IFRS adoption. Hence, we establish the second hypothesis as below.
H2: Effect of improving earnings quality after the IFRS adoption would be greater for KOSDAQ listed firms than KOSPI listed firms.

\section{RESEARCH DESIGN}

\subsection{Research models}

The research models for testing hypotheses 1 and 2 are as follows:

$$
\begin{aligned}
& D A(M J, P M D A)_{i t}=\alpha_{0}+\alpha_{1} \cdot I F R S_{i t}+ \\
& +\alpha_{2} \cdot S I Z E_{i t}+\alpha_{3} \cdot L E V_{i t}+\alpha_{4} \cdot M B_{i t}+ \\
& +\alpha_{5} \cdot R O A_{i t}+\alpha_{6} \cdot B I G 4_{i t}+\alpha_{7} \cdot F O R G I_{i t}+ \\
& +\alpha_{8} \cdot O W N E R+I N D+Y D+e
\end{aligned}
$$

$$
\begin{aligned}
& D A(M J, P M D A)_{i t}=\alpha_{0}+\alpha_{1} \cdot I F R S_{i t}+ \\
& +\alpha_{2} \cdot \operatorname{KOSDAQ_{it}}+\alpha_{3} \cdot \operatorname{IFRS} \cdot \operatorname{KOSDA} Q_{i t}+ \\
& +\alpha_{4} \cdot \operatorname{SIZE}_{i t}+\alpha_{5} \cdot L E V_{i t}+\alpha_{6} \cdot M B_{i t}+ \\
& +\alpha_{7} \cdot R O A_{i t}+\alpha_{8} \cdot B_{I G 4_{i t}}+\alpha_{9} \cdot \text { FORGI }_{i t}+ \\
& +\alpha_{10} \cdot O W N E R_{i t}+I N D+Y D+e,
\end{aligned}
$$

where $D A$ : discretionary accruals measured by both modified Jones model (MJ) and performance-matched discretionary accruals (PMDA); IFRS: 1 if post-IFRS and 0 otherwise; KOSDAQ: 1 if KOSDAQ listed firm and 0 otherwise; SIZE: the natural logarithm of total assets; $L E V$ : total liabilities divided by beginning total assets; $M B$ : market value divided by book value; $R O A$ : net income divided by beginning total assets; BIG4: 1 if auditor is a large auditor (called Big 4) and 0 otherwise; FORGI: ownership of foreign investors; OWNER: ownership of largest shareholder and related parties; IND: industry dummy; YD: year dummy.

This study uses discretionary accruals $(D A)$ as the proxy of earnings quality following prior studies. $D A$ is measured by such models as modified Jones model (MJ) of Dechow et al. (1995) and performance-matched discretionary accruals model (PMDA) of Kothari et al. (2005). Further, absolute values of $D A$ are used in estimating equation (1) and equation (2) following prior studies ${ }^{3}$.

2 We establish the first hypothesis in the form of null hypothesis because of inconsistent results of prior studies.

3 The results of hypotheses testing are similar when using the residual values estimated by modified Jones model (MJ) and performancematched discretionary accruals model (PMDA) instead of absolute values. 
Korean listed firms applied Korean GAAP before the IFRS adoption and disclosed consolidated financial statements after announcing individual financial statements following related laws. In other words, main financial statements of Korean listed firms of which accounting information users mainly utilized were individual financial statements before the IFRS adoption. However, after the IFRS adoption, consolidated financial statements are disclosed as main financial statements and individual financial statements are included in foot note of consolidated financial statements. Thus, this study considers both individual financial statements and consolidated financial statements in estimating equations (1) and (2) in order to improve the comparability of earnings quality for pre-IFRS period and post-IFRS period.

The main explanatory variable of Equation (1) which tests for hypothesis 1 is IFRS. Thus, if estimated coefficient of $\alpha_{1}$ has significant negative value, it means $D A$ of Korean listed firms decreased after the IFRS adoption. In other words, it indicates that earnings quality of Korean listed firms was improved after the IFRS adoption and hypothesis 1 can't be supported.

The main explanatory variable of equation (2) which tests the hypothesis 2 is IFRS $\cdot \mathrm{KOSPI}_{t}$ . Accordingly, if estimated coefficient of $\alpha_{3}$ has significant negative value, hypothesis 2 which predicts earnings quality of KOSDAQ-listed firms would be improved greater than that of KOSPIlisted firms after the IFRS adoption is supported. Control variables (SIZE, $L E V, M B, R O A, B I G 4$, FORGI, OWNER) are included following related prior studies.

\subsection{Sample selection}

This study analyzed all listed firms in KOSPI and KOSDAQ market from 2006 to 2015. Specifically, this study treated 2006-2010 as pre-IFRS period and 2011-2015 as post-IFRS period, respectively. Sample firms were selected from the following conditions:

(1) firms listed in KOSPI and KOSDAQ market from 2006 to 2015 ;

(2) non-financial firms;
(3) firms which close their books in December;

(4) firms with data available on KIS-VALUE;

(5) firms without impaired capital not under administration and not delisted.

All data for the analysis were collected from KISVALUE and extreme values of all variables were winsorized at $1 \%$ level of both tale. The final firmyear observations were $13.154(n=13.154)$.

\section{EMPIRICAL RESULTS}

\subsection{Descriptive statistics and correlation analysis}

Table 1 shows descriptive statistics of variables included in Equations (1) and (2). MJ(Ind.) and PMD (Ind.) stand for discretionary accruals on individual financial statements measured by modified Jones model and performance-matched discretionary accruals model, respectively. MJ(Con.) and PMDA(Con.) stand for discretionary accruals on consolidated financial statements measured by modified Jones model and performance-matched discretionary accruals model, respectively.

All means, minimum values, maximum values of four variables measuring $D A$ [ $M J$ (Ind.), PMDA(Ind.), MJ(Con.), PMDA(Con.)] have positive value, because they are measured by absolute values. Considering means of $M J$ (Ind.) and PMDA(Ind.) is lower than those of MJ(Con.) and $P M D A$ (Con.), it is found that earnings quality on individual financial statements of Korean listed firms is at a higher level than earnings quality on the consolidated financial statements during research periods. This may be due to the fact that individual financial statements were mainly used for economic decision making in Korea before the IFRS adoption.

The average of IFRS variables is 0.5607 which means that about $56 \%$ of total observations consist of the period after the IFRS adoption. In addition, the average of KOSDAQ is 0.5904 , that is, KOSDAQ-listed firms consist of about $59 \%$ of total observations. Thus, the sample composition for the analysis is relatively stable. 
Table 1. Descriptive statistics ( $n=13,154)$

\begin{tabular}{|c|c|c|c|c|c|c|c|}
\hline Variables & Mean & Std. & Min. & 1Q & Median & $3 Q$ & Max. \\
\hline MJ(Ind.) & 0.059145 & 0.057049 & 0.0000003 & 0.017872 & 0.041543 & 0.080502 & 0.276297 \\
\hline PMDA(Ind.) & 0.058149 & 0.055876 & 0.0000015 & 0.017819 & 0.041074 & 0.079877 & 0.271936 \\
\hline MJ(Con.) & 0.071911 & 0.073586 & 0.0000006 & 0.021415 & 0.048151 & 0.095974 & 0.361047 \\
\hline PMDA(Con.) & 0.069291 & 0.068758 & 0.0000049 & 0.021013 & 0.047242 & 0.093145 & 0.323125 \\
\hline IFRS & 0.560666 & 0.496325 & 0 & 0 & 1 & 1 & 1 \\
\hline KOSDAQ & 0.590391 & 0.491780 & 0 & 0 & 1 & 1 & 1 \\
\hline BIG4 & 0.551163 & 0.497394 & 0 & 0 & 1 & 1 & 1 \\
\hline SIZE & 25.633250 & 1.386414 & 23.242606 & 24.698487 & 25.362952 & 26.301336 & 30.33015 \\
\hline LEV & 0.443281 & 0.240326 & 0.035276 & 0.254505 & 0.428605 & 0.597982 & 1.222846 \\
\hline $\mathrm{MB}$ & 1.020487 & 1.183002 & 0.084029 & 0.373154 & 0.642836 & 1.164085 & 7.622867 \\
\hline ROA & 0.023643 & 0.113904 & -0.472170 & -0.002452 & 0.032980 & 0.076898 & 0.321598 \\
\hline FORGI & 0.062390 & 0.109065 & 0.000000 & 0.002100 & 0.013100 & 0.068700 & 0.553500 \\
\hline OWNER & 0.273303 & 0.140750 & 0.047100 & 0.167800 & 0.246900 & 0.350400 & 0.700000 \\
\hline
\end{tabular}

Table 2 presents Pearson correlation between the variables. It shows that all four variables measuring $D A[M J($ Ind.), $P M D A($ Ind.), $M J(C o n$.), $P M D A(C o n$.)] have a significant negative correlation with IFRS. Thus, it is supposed that overall discretionary accruals on not only individual financial statements, but also consolidated financial statements have significantly decreased after the IFRS adoption. Moreover, $M J$ (Ind.), PMDA(Ind.), $M J(C o n),. P M D A(C o n$.) have significant positive correlation with KOSDAQ. It indicates that earnings quality of KOSDAQ-listed firms is at a lower level than that of KOSPI-listed firms. The results of Table 2 can support the logical basis of hypothesis 2 which predicts effect of improving earnings quality after the IFRS adoption would be greater for KOSDAQ-listed firms than KOSPI-listed firms.

\subsection{Test results of hypotheses}

Table 3 provides test results of Equation (1) for hypothesis 1. IFRS has significant negative relationship with all four dependent variables measuring $D A[M J($ Ind.), PMDA(Ind.), MJ(Con.), $P M D A(C o n)$.$] . In other words, earnings quality on$ both individual financial statements and consolidated financial statements of Korean listed firms has significantly improved after the IFRS adoption. In addition, most control variables included in the

Table 2. Pearson correlation matrix $(n=13,154)$

\begin{tabular}{|c|c|c|c|c|c|c|c|c|c|c|c|c|c|}
\hline & V1 & V2 & V3 & V4 & V5 & V6 & V7 & V8 & V9 & V10 & V11 & V12 & V13 \\
\hline $\mathrm{MJ}(\mathrm{Ind}$.) (V1) & 1.00 & & & & & & & & & & & & \\
\hline PDMA(Ind.) (V2) & 0.95 & 1.00 & & & & & & & & & & & \\
\hline MJ(Con.) (V3) & 0.62 & 0.59 & 1.00 & & & & & & & & & & \\
\hline PDMA(Con.) (V4) & 0.60 & 0.62 & 0.92 & 1.00 & & & & & & & & & \\
\hline IFRS (V5) & -0.13 & -0.13 & -0.12 & -0.11 & 1.00 & & & & & & & & \\
\hline KOSDAQ (V6) & 0.15 & 0.05 & 0.16 & 0.15 & 0.04 & 1.00 & & & & & & & \\
\hline BIG4 (V7) & -0.05 & -0.05 & -0.07 & -0.07 & -0.01 & -0.23 & 1.00 & & & & & & \\
\hline SIZE (V8) & -0.18 & -0.18 & -0.21 & -0.19 & 0.11 & -0.57 & 0.36 & 1.00 & & & & & \\
\hline LEV (V9) & 0.17 & 0.17 & 0.15 & 0.15 & -0.08 & -0.06 & 0.02 & 0.12 & 1.00 & & & & \\
\hline MB (V10) & 0.14 & 0.13 & 0.13 & 0.12 & 0.05 & 0.18 & -0.01 & -0.20 & -0.08 & 1.00 & & & \\
\hline ROA (V11) & -0.01 & 0.01 & -0.23 & -0.20 & -0.05 & -0.04 & 0.12 & 0.10 & -0.13 & 0.14 & 1.00 & & \\
\hline FORGI (V12) & -0.07 & -0.07 & -0.07 & $0-07$ & -0.02 & -0.26 & 0.24 & 0.45 & -0.08 & 0.11 & 0.16 & 1.00 & \\
\hline OWNER(V13) & -0.02 & -0.02 & -0.07 & -0.06 & 0.04 & -0.06 & 0.12 & 0.06 & -0.02 & -0.05 & 0.13 & 0.03 & 1.00 \\
\hline
\end{tabular}

Note: The lower triangle presents the Pearson correlation coefficients. Boldfaced figures are statistically significant at the 5\% level. 
Table 3. Test results of hypothesis 1

\begin{tabular}{|c|c|c|c|c|}
\hline & \multicolumn{2}{|c|}{ Individual } & \multicolumn{2}{|c|}{ Consolidated } \\
\hline \multirow{3}{*}{ Dependent Variable } & MJ & PMDA & MJ & PMDA \\
\hline & Coefficient & Coefficient & Coefficient & Coefficient \\
\hline & (t-stat.) & (t-stat.) & (t-stat.) & (t-stat.) \\
\hline \multirow{2}{*}{ Intercept } & $0.22653^{* * *}$ & $0.2139^{* * *}$ & $0.2714^{* * *}$ & $0.2905^{* * *}$ \\
\hline & $(20.62)$ & $(19.8)$ & $(20.74)$ & $(21.03)$ \\
\hline \multirow{2}{*}{ IFRS } & $-0.0122^{* * *}$ & $-0.0114^{* * *}$ & $-0.0116^{* * *}$ & $-0.0143^{* * *}$ \\
\hline & $(-5.96)$ & $(-5.68)$ & $(-4.75)$ & $(-5.57)$ \\
\hline \multirow{2}{*}{ SIZE } & $-0.0073^{* * *}$ & $-0.0068^{* * *}$ & $-0.0086^{* * *}$ & $-0.0093^{* * *}$ \\
\hline & $(-16.95)$ & $(-16.06)$ & $(-16.58)$ & $(-16.97)$ \\
\hline \multirow{2}{*}{ LEV } & $0.0460 * * *$ & $0.0431^{* * *}$ & $0.0420^{* * *}$ & $0.0437^{* * *}$ \\
\hline & $(22.47)$ & $(21.4)$ & $(17.21)$ & (16.97) \\
\hline \multirow{2}{*}{$\mathrm{MB}$} & $0.0061^{* * *}$ & $0.0056^{* * *}$ & $0.0075^{* * *}$ & $0.0091^{* * *}$ \\
\hline & $(14.04)$ & $(13.25)$ & $(14.57)$ & $(16.73)$ \\
\hline \multirow{2}{*}{ ROA } & 0.0053 & 0.0074 & $-0.1060^{* * *}$ & $-0.1393^{* * *}$ \\
\hline & $(1.23)$ & $(1.73)$ & $(-20.92)$ & $(-26.03)$ \\
\hline \multirow{2}{*}{ BIG4 } & 0.0011 & 0.0006 & 0.0013 & 0.0015 \\
\hline & $(1.15)$ & $(0.63)$ & $(1.08)$ & $(1.19)$ \\
\hline \multirow{2}{*}{ FORGI } & 0.0047 & 0.0039 & $0.02372 * * *$ & $0.0256^{* * *}$ \\
\hline & $(0.92)$ & $(0.79)$ & $(3.89)$ & (3.98) \\
\hline \multirow{2}{*}{ OWNER } & -0.0011 & 0.0033 & $-0.0072^{*}$ & $-0.0083^{*}$ \\
\hline & $(-0.32)$ & $(-0.09)$ & $(-1.78)$ & $(-1.95)$ \\
\hline IND & Included & Included & Included & Included \\
\hline YD & Included & Included & Included & Included \\
\hline Adj. R2 & 0.0994 & 0.0921 & 0.1211 & 0.1447 \\
\hline Obs. & 13,154 & 13,154 & 13,154 & 13,154 \\
\hline
\end{tabular}

Note: ${ }^{*}{ }^{* *},{ }^{* *}$ represent significance at the 10,5 , and 1 percent levels, respectively.

model were also significantly associated with dependent variables. Therefore, this study found no evidence generally supporting hypothesis 1 , which expects earnings quality of Korean listed firms would not be different after the IFRS adoption in comparison with that before IFRS adoption.

Table 4 provides test results of Equation (2) for hypothesis 2 . As in Table 3, Table 4 also shows significant negative associations between IFRS and all dependent variables [MJ(Ind.), PMDA(Ind.), $M J(C o n),. P M D A(C o n)$.$] . And KOSDAQ has sig-$ nificant positive relationships with all dependent variables. It means that the level of discretionary accruals of KOSDAQ-listed firms is greater than that of KOSPI-listed firms likewise in Table 2.
IFRS $\cdot K O S D A Q$ have a significant negative relationship with dependent variables measured by consolidated financial statements data $[M J(C o n$.$) ,$ $P M D A($ Con.)]. On the contrary, no significant association is found between IFRS $\cdot K O S D A Q$ and dependent variables measured by individual financial statements data [MJ(Ind.), PMDA(Ind.)]. These results may be attributed to the fact that the main financial statements were altered from individual financial statements to consolidated financial statements after the IFRS adoption. Combing results of Table 4, it can be interpreted that the earnings quality of KOSDAQ-listed firms was improved greater than earnings quality of KOSPIlisted firms after the IFRS adoption. Hence, we found evidence generally supporting hypothesis 2 . 
Table 4. Test results of hypothesis 2

\begin{tabular}{|c|c|c|c|c|}
\hline & \multicolumn{2}{|c|}{ Separate } & \multicolumn{2}{|c|}{ Consolidated } \\
\hline \multirow{3}{*}{$\begin{array}{l}\text { Dependent } \\
\text { Variable }\end{array}$} & MJ & PDMA & MJ & PDMA \\
\hline & Coefficient & Coefficient & Coefficient & Coefficient \\
\hline & (t-stat.) & (t-stat.) & (t-stat.) & (t-stat.) \\
\hline \multirow{2}{*}{ Intercept } & $0.1772 * * *$ & $0.1602^{* * *}$ & $0.2131^{* * *}$ & $0.2296^{* * *}$ \\
\hline & $(13.72)$ & $(12.61)$ & $(13.85)$ & $(14.14)$ \\
\hline \multirow{2}{*}{ IFRS } & $-0.0122 * * *$ & $-0.0118^{* * *}$ & $-0.0083^{* * *}$ & $-0.0085^{* * *}$ \\
\hline & $(-5.18)$ & $(-5.09)$ & $(-2.98)$ & $(-2.90)$ \\
\hline \multirow{2}{*}{ KOSDAQ } & $0.0090^{* * *}$ & $0.0095^{* * *}$ & $0.0134^{* * *}$ & $0.0160^{* * *}$ \\
\hline & $(5.70)$ & $(6.12)$ & $(7.08)$ & (7.99) \\
\hline \multirow{2}{*}{ IFRS*KOSDAQ } & -0.0010 & -0.0005 & $-0.0065^{* *}$ & $-0.0107^{* * *}$ \\
\hline & $(-0.53)$ & $(-0.27)$ & $(-2.85)$ & $(-4.45)$ \\
\hline \multirow{2}{*}{ SIZE } & $-0.0056^{* * *}$ & $-0.0049^{* * *}$ & $-0.0066^{* * *}$ & $-0.0072^{* * *}$ \\
\hline & $(-11.40)$ & $(-10.23)$ & $(-11.2)$ & $(-11.66)$ \\
\hline \multirow{2}{*}{ LEV } & $0.0456^{* * *}$ & $0.0426^{* * *}$ & $0.0415^{* * *}$ & $0.0432 * * *$ \\
\hline & $(22.29)$ & $(21.2)$ & $(17.02)$ & $(16.78)$ \\
\hline \multirow{2}{*}{$\mathrm{MB}$} & $0.0059^{* * *}$ & $0.0054^{* * *}$ & $0.0073^{* * *}$ & $0.0089^{* * *}$ \\
\hline & $(13.60)$ & $(12.77)$ & $(14.17)$ & $(16.36)$ \\
\hline \multirow{2}{*}{ ROA } & 0.0044 & 0.0064 & $-0.1066^{* * *}$ & $-0.1398^{* * *}$ \\
\hline & $(1.03)$ & $(1.50)$ & $(-21.07)$ & $(-26.17)$ \\
\hline \multirow{2}{*}{ BIG4 } & 0.0014 & 0.0008 & 0.0015 & 0.0017 \\
\hline & $(0.17)$ & $(0.87)$ & $(1.29)$ & $(1.38)$ \\
\hline \multirow{2}{*}{ FORGI } & 0.0046 & 0.0038 & $0.0238^{* * *}$ & $0.0258^{* * *}$ \\
\hline & $(0.91)$ & $(0.77)$ & $(3.91)$ & $(4.02)$ \\
\hline \multirow{2}{*}{ OWNER } & -0.0004 & 0.0005 & $-0.0067^{*}$ & $-0.0081^{*}$ \\
\hline & $(-0.12)$ & $(0.15)$ & $(-1.67)$ & $(-1.90)$ \\
\hline IND & Included & Included & Included & Included \\
\hline YD & Included & Included & Included & Included \\
\hline Adj. R2 & 0.1028 & 0.0963 & 0.1247 & 0.1488 \\
\hline Obs. & 13,154 & 13,154 & 13,154 & 13,154 \\
\hline
\end{tabular}

Note: ${ }^{*},{ }^{* *},{ }^{* *}$ represent significance at the 10,5 , and 1 percent levels, respectively.

\section{SUMMARY AND CONCLUSION}

Prior studies analyzing whether earnings quality is improved after the IFRS adoption didn't provide consistent results. Moreover, although effects of the IFRS adoption may be occurred for relatively long term, prior studies which analyzed relationship between earnings quality and IFRS adoption in Korea had a limitation in that they used short-term analysis.

Thus, this study analyzed Korean evidence of the IFRS adoption effect with respect to improvement of earnings quality in long term perspective. Specifically, this study utilized 5 year periods before and after IFRS adoption, respectively. Moreover, the effect of the IFRS adoption on earnings quality was comparatively analyzed for each Korean stock market (KOSPI and KOSDAQ). Earnings quality was measured by discretionary accruals. Especially, individual financial statements data, as well as consolidated financial statements data were analyzed considering Korean specific institutional environment in which main financial statements prepared and disclosed by listed firms were changed from individual financial statements to consolidated financial statements after the IFRS adoption. 
Empirical results found that overall earnings quality of Korean listed firms were significantly improved during 5 years after the IFRS adoption regardless of their listing market and types of financial statements. In addition, earnings quality on consolidated financial statements of KOSDAQ-listed firms has improved greater than that of KOSPI-listed firms. However, no significant difference was found in earnings quality on individual financial statements between KOSDAQ-listed firms and KOSPI-listed firms.

This paper is different from prior studies, as it investigated the IFRS adoption effect using long-term based approach. Furthermore, this study comparatively analyzed the IFRS adoption effect for each Korean stock market. This study has meaningful implications to assess whether fundamental purpose of the IFRS adoption in Korea has been achieved.

\section{REFERENCES}

1. Bae, D. S., \& Choi, S. M. (2013). IFRS Adoption and Earnings Management. Korean Journal of Accounting Research, 18(2), 117145. Retrieved from http://www. dbpia.co.kr/Journal/ArticleDetail/ NODE02192093

2. Barth, M., Landsman, W., \& Lang, M. (2008). International accounting standards and accounting quality. Journal of Accounting Research, 46(3), 467498. Retrieved from http://www. jstor.org/stable/40058143

3. Callao, S., \& Jarne, J. I. (2010). Have IFRS Affected Earnings Management in the European Union? Accounting in Europe, 7(2), 159-189. Retrieved from http:// eds.b.ebscohost.com/ehost/detail/ detail?vid=2\&sid=44d15856-8ed 1 4c21-8459-3e1a02fa605d\%40sessi onmgr103\&bdata $=$ Jmxhbmc9a28 mc210ZT1laG9zdC1saXZl\#db=bth $\& \mathrm{AN}=55473598$

4. Chen, H., Tang, Q., Jiang, Y., \& Lin, Z. (2010). The Role of International Financial Reporting Standards in Accounting Quality: Evidence from the European Union. Journal of International
Financial Management and Accounting, 21(3), 220-278. Retrieved from http://onlinelibrary.wiley.com/doi/10.1111/ j.1467-646X.2010.01041.x/full

5. Dechow, P., Sloan, R., \& Sweeny, A. (1995). Detecting Earnings Management, The Accounting Review, 70, 193-225. Retrieved from http://eds.b.ebscohost. com/ehost/pdfviewer/ pdfviewer?vid $=2 \&$ sid $=8 \mathrm{e} 7 \mathrm{~d} 1801$ cd54-44ee-9b55b8f917cc48d7\%40sessionmgr104

6. Kothari, S., Leone A., \& Wasley, C. (2005). Performance Matched Discretionary Accruals Measures. Journal of Accounting and Economics, 39(1), 163197. Retrieved from https://doi. org/10.1016/j.jacceco.2004.11.002

7. Li, J., \& Park, S. K. (2012). Earnings Management Effects of IFRS Adoption and Ownership Structure: Evidence from China. Korea International Accounting Review, 41, 121-136. Retrieved from http://www.dbpia.co.kr/Journal/ArticleDetail/NODE01797238

8. Moon, H. J. (2017). A Comparison of Earnings Quality between
KOSPI Firms and KOSDAQ Firms. Journal of Digital Convergence, 15(1), 129-141. Retrieved from http://www.earticle.net/article. aspx?sn=292809

9. Jeong, T.B. (2013). Adoption of IFRS and Earnings Management. Korean Accounting Review, 22(1), 327-348. Retrieved from http://kiss.kstudy.com/ journal/thesis_name.asp?tname $=$ kiss2002\&key $=3128504$

10. Tendeloo, B. V., \& Vanstraelen, A. (2005). Earnings Management under German GAAP versus IFRS. European Accounting Review, 14(1), 155-180. Retrieved from http://eds.b.ebscohost.com/ehost/ detail/detail?vid=2\&sid=f31e6dc53113-4312-b6a2-df38934c150f\%40 sessionmgr104\&bdata $=$ Jmxhbmc9 a28mc210ZT1laG9zdC1saXZl\#AN $=17384887 \& \mathrm{db}=\mathrm{bth}$

11. Yoon, S. S., \& Kim, H. J. (2007). Earnings Management of KOSDAQ Venture IPO Firms. Accounting Information Review, 25(4), 29-57. Retrieved from http://kiss.kstudy.com/ journal/thesis_name.as$\mathrm{p} ?$ tname $=$ kiss $2002 \& \mathrm{key}=2662000$ 